\title{
ACCOUNTING CONSERVATISM AND INVESTMENT EFFICIENCY OF LISTED NIGERIAN CONGLOMERATE FIRMS
}

\author{
Lawal Aminu \\ Department of Accounting Kaduna State University (KASU)-Nigeria \\ Shehu Usman Hassan PhD \\ Department of Accounting Kaduna State University (KASU)-Nigeria
}

OScholedge International Journal of Business Policy \& Governance (ISSN 2394-3351), Vol.03, Issue 11 (2016) pg167-177. Published by: Scholedge R\&D Center [www.theSCHOLEDGE.org] [Email: editorial@thescholedge.org]

\begin{abstract}
This study explores the relationship between Accounting conservatism and investment efficiency in Nigeria. The study model examined the relationship between the independent variables (Accounting conservatism) and the dependent variable of investment efficiency, by applying the simple regression analysis of 10 years data Ordinary Least Squares (OLS) which cover the period of 2005-2014. All of tests have been done using stata11 statistical software. The results obtained from this research indicate that there is a significant relationship between accounting conservatism and investment efficiency. The study concluded that there is a positive relationship between Accounting conservatism and investment efficiency in Nigerian conglomerate firms. The study suggest that need to embrace the element of conservatism in to the accounting regulatory framework, because of it role in constraining managers to act efficiently in an investment monitoring and decision making.
\end{abstract}

Keywords: Accounting conservatism, investment efficiency, Nigerian conglomerates.

\section{Introduction}

The predicted relationship between the accounting conservatism and firm investment based on accounting literature is mixed. In line with agency theory, managers have more information about the expected benefit, project delivery time, and investments in hand (Lambert, Leuz and Verrecchia 2007). Thus, they can make investment decisions which may harm the interests of investors (Jensen and Meckling 1976). Accounting conservatism, through the Quick recognition of economic losses in the income statement, is predicted to increase firm investment efficiency through three main channels; by decreasing the negative effects of information asymmetries and facilitating the monitoring of managerial investment decisions; by increasing managerial incentives to abandon poorly performing projects earlier and to undertake fewer negative net present-value investments; and by facilitating access to external financing at lower cost (Lalbar, Ghaemmaghami, Pourmansoor, \& Karamali, 2012).

Several studies have examined accounting conservatism in different economic and financial environments (Ahmed, Billing, Morton \& Stanford-Harris, 2002; Ahmed, \& Duellman, 2007a, 2007b; Basu, 1997; Ball, Kothari \& Robin, 2000; Ball \& Shivakumar 2005; Biddle \& Hilary, 2006; Biddle, Hilary, \& Verdi, 2009; Brochman, Liu, \& Ma, 2010; Bushman, Piotroski \& Smith, 2007; Bushman \& Smith, 2001; Gary, Mary \& Franek, 2010; Geimechi \& Khodabakhshi, 2015; Ghavi, Najafi \& Arfai, 2013; Guay \& Verrecchia, 2007; Hope \& Thomas, 2008; Jensen, 1986; Jensen \& Meckling, 1976; Julio, 2007; Lafound \& Watt, 2008; Lara, Osma, \& Penalva, 2009, 2010a, 2010b; lalbar et al 2012; Lambert et al 2007; Mahmoodabadi \& Mehtari, 2012; Mansoori \& Kiamehr, 2014; Mcnichols \& Stubben, 2008; Myers, 1977; Myers \& Majluf, 1984; Nakano, Ostubo \& Takasa, 2014; Naunprdit \& Boomlert-U-Thai, 2013; Schleicher, Tahoun \& Walker, 2008; Suijs, 2008; Stein, 1989; Verdi, 2006; Xu, Wang \& Han, 2012). Despite the relevance of the studies so far, they have examine the relationship between the Accounting conservatism and investment efficiency in a different geographical environment. That is, there are no empirical studies so far 
examining the effect of accounting conservatism on firm investment in Nigeria. Therefore, we posed the following research problem: Do the Accounting conservatism affect the firm investment efficiency of Nigeria conglomerate firms? This study fills this gap and makes initial efforts to examine the effect of accounting conservatism on firm investment efficiency in Nigerian conglomerate firms.

The main objective of this study is to determine the relationship between Accounting Conservatism and investment efficiency in Nigerian Conglomerate firms. In line with the objective of the study, the following hypothesis has been formulated in null form:

Ho: There is no significant impact of accounting conservatism on investment efficiency in Nigerian Conglomerate firms.

The significance of this study seize to being only an extension of the accounting knowledge in the field of accounting conservatism and investment efficiency by clarifying the concept of accounting conservatism and concept of investment efficiency. The study would also provides new insights analysis of the effects of accounting conservatism (higher quality reporting) over investment efficiency (Biddle and Hilary 2006; McNichols and Stubben 2008; Biddle, Hilary and Verdi 2009;Bushman, Piotroski and Smith 2007; Ahmed and Duellman 2007). These study findings may suggest that firm commitment to conservatism can lead to a direct benefit to international and local investors in the form of more efficient investments.

\section{Literature Review and Theory}

An efficient investment policy can be defined as one in which all positive NPV investment projects are identified, funded and implemented, while all negative NPV projects are rejected (Julio 2007). Agency theory predicts that whilst managers may be well informed about the existence of profitable investment opportunities, they might not always pursue them because of, first, moral hazard problems that derive in managerial expropriation of firm cash flows, myopic biases and inefficient selection of investment opportunities (Jensen \& Meckling 1976; Jensen 1986; Stein 1989); and secondly, lack of available funding derived from high cost of external financing. This high cost of equity capital can be due to the firm capital structure, which might drive a wedge between the overall return to investment and the return accrued to shareholders; but it can also be partly attributable to information asymmetries and complications in the estimation of the firm's future cash flows (lara et al, 2009).

Accounting information plays an important role in monitoring senior managers (Bushman \& Smith, 2001), contributing toward making moral hazard problems better and to decrease the problems created by information asymmetries (lara etal 2009), and, as shown by Lambert et al (2007) it facilitates the estimation of firms' future cash flows. As suggested by Bushman and Smith (2001) and Lambert et al (2007), these effects are expected to increase firm value by improving firm's investment decisions. Empirical research by Biddle and Hilary (2006), McNichols and Stubben (2008), Biddle et al (2009) and Hope and Thomas (2008) confirms that the quality of accounting information and disclosure affects investment efficiency. In particular, Biddle and Hillary (2006) document a positive association at the country- and firm-levels between investment-cash flow sensitivity and information fact of being opaque. In a similar vein, Schleicher, Tahoun and Walker (2008) show that IFRS adoption in Europe contributes to lower investment cash-flow sensitivity, Biddle et al (2009) find that increased accruals quality is associated to lower over- and underinvestment and McNichols and Stubben (2008) show that firms that manipulate their reported earnings make sub optimal investment decisions during the misreporting period. Finally, Hopeand Thomas (2008) demonstrates that not disclosing geographic segment information has a negative effect on the efficiency of foreign investment.

Bushman et al (2007) provided evidence consistent with a negative relation between country-level measures of investment cash flow sensitivity and country-level measures of conservatism. From a different methodological perspective, Ahmed and Duellman (2007) find evidence that more conservative firms present higher future profitability measures like gross profit margins and cash flows, and less special item charges. They interpret this evidence as indicative of more conservative firms investing more efficiently.

Accounting literatures argues conservatism influences firm investment efficiency in three main ways, Firstly, conservatism emerges as a reaction to information asymmetry. Conservatism mitigates the existing information 
asymmetries between managers and external investors by narrowing managerial skills and providing higher stability and high quality financial reporting (LaFond \& Watts 2008). This is in consistent with the work of Ahmed and Duellman (2009) that conservatism is associated with strong corporate governance mechanisms that decrease the CEO's power and improve monitoring.

Secondly, by requiring early recognition of poor realizations, conservatism plays a significant role in resolving managerial agency conflicts. As argued by Ball and Shivakumar (2005), because losses have to be recognised in a timelier manner, managers are aware that they will not be able to defer the earnings consequences of their investment decisions to the next generation of managers; i.e., managers have to bear the consequences of their investment decisions during their tenure. This is predicted to limit managerial investments in ex ante negative net present value (NPV) projects, reducing the likelihood of managers engaging in empire building strategies, 'pet' projects or 'trophy' acquisitions. Similarly, conservatism is predicted to trigger the early abandonment of ex post poorly performing projects and deter strategies of continuing (over) investment in underperforming projects. Under conservative reporting, because loss recognition cannot be deferred, managers opt to abandon negative NPV projects earlier. Thus, timely loss recognition is expected to increase managerial incentives to react quickly to negative realizations, limiting losses on projects that do not perform (lara et al 2009).

Thirdly, conservatism reduces the conflicts between the bondholders (the financiers) and shareholders over share dividends, and it also results in lower cost of financing through borrowing, hence less risk in debt collection (Myers 1977, 1984 and lalbar et al 2012). This, by itself, reduces the debt caused by negative effect on investment efficiency (Ahmed, Billings, Morton, \& Stanford, 2002). It is predicted that conservative accounting will mitigate the cost of equity capital (Guay \& Verrecchia, 2007; Suijs, 2008).It is also expected that these reductions in the costs of debts and equity capital, will facilitate the opportunities of financial investment (lalbar et al 2012).

According to Kieso, Weygandt and Warfield (2001) relatively associated with minimum unwanted consequences; accounting conservatism is an approach to take when in doubt about choosing a procedure that would not unfavorably reflect the assets and profit higher than the actual values. From the viewpoint of Pure (1998), conservative behavior is an approach that prioritizes lower incomes (compared to higher incomes), and higher costs (compared to lower costs), and thus while identifying the unpredicted losses, it does not identify the unrealized profits. Conservative accounting results in an increase in the firm's liquid assets, by reducing the outflow and increasing the inflow of liquidity through a decrease in cash investments, avoiding from investing in negative net present value projects, keeping the agency cost at a low level, and increasing the savings level (Gary et al, 2010).

The contribution of this study to the literature consist among, suggestion that eliminating conservatism from accounting regulatory frameworks by Financial Reporting Council and International Financial Reporting Standard Board, may cause undesirable economic outcomes, especially to the developing economy like nigeria, considering statistically positive significance of conservatism on investment efficiency. Again, the most profitable and fast growing Nigerian conglomerate firms are more conservative firms investing more efficiently to the benefit of both the international and local investors.

\section{Methodology and Model specification}

This study is quantitative in nature (positivism paradigm) and secondary data is used. Correlational research design is used to describe the statistical association between two or more variables. The regression analysis is used to test the relationship between variables of the model. The sample of the study consists of all the 8 conglomerate firms listed on the Nigerian Stock Exchange (NSE) for the period between 2004 to 2013, making 80 observations. Measuring of dependent Variables: This study adopted Mansoori and Kiamehr (2014) model for measuring investment efficiency in which, investment has been considered as the cash paid for acquisition or construction of fixed assets; intangible assets or other noncurrent assets (COF) divided by total assets at the beginning of period (TA). The study adopted lalbar et al (2012) model in which conditional conservatism is used as Accounting conservatism proxy, since the lower the value of non-operating accrual the higher the level of firm conservatism (lalbar et al, 2012). However, the Control variables of this study are firm size and firm leverage, in which firm size is the Natural logarism of firm Total asset at the end of period and firm leverage, is the firm total debt to the total assets at the end of period. 


\section{Model specification}

The model designed for the study is given as:

$$
\text { INVEFF }_{i t}=\alpha+\beta_{1} \operatorname{CON}_{i t}+\beta_{2} \operatorname{SIZE}_{i t}+\beta_{3} L E V_{i t}+\varepsilon
$$

\section{Where:}

INVEFF: Investment efficiency $={ }^{\mathrm{COF}} / \mathrm{TA}$, as dependent variable

i:firm

t:period/time

a: Constant value.

$\beta_{1-3}$ : coefficient of independent variable.

CON:AccountingConservatism(conditional $)=\mathrm{NoACC}_{\mathrm{it}} / \mathrm{TA}_{\mathrm{it}}(-1)$, as Independent variable.

SIZE: firm size $=\log ($ Asset $)$, as Control variable.

LEV: firm levarege $=$ The total debt to the total assets at the end of period, as Control variable.

$\varepsilon=$ Error term.

Non-operating accruals (NOACC) can be calculated by the following relations:

$A C C=N I+D E P-C F O$

$O A C C=\Delta I+\triangle A R+\triangle P E-\triangle A P-\triangle T P$

NOACC $=$ ACC - OACC

in which:

$\Delta l:$ Change in Inventory

$\triangle A R$ : Change in Accounts Receivable

$\triangle P E$ : Change in Prepaid Expenses

$\triangle A P$ : Change in Accounts Payable

$\Delta T P$ : Change in Taxes Payable

NoACC: Non-operational Accruals

ACC: Total accruals

$\mathrm{Nl}$ :Net profit before Items

DEP: Depreciation Expense Payable

CFO: Cash Flow from Operations 
oACC: Operational Accruals

The tests of robustness is (multicollinearity, heteroscedasticity, and test of serial correlation) conducted in order to improve the validity of all statistical inferences for the study, see appendix.

\section{Result and Discussion}

In this section, the study's results are presented and discussed. The descriptive statistics are first presented, then followed by the regression results.

Table 1: Descriptive Statistics

\begin{tabular}{llllll}
\hline VARIABLES & Mean & Std Dev & Min & Max & N \\
\hline INVEFF & 0.5332762 & 0.2048363 & 0.0538 & 0.9479 & 80 \\
CON & 0.0234287 & 0.1866834 & 0.4951 & 0.9022 & 80 \\
LEVR & 0.1992225 & 0.0951834 & 0.0446 & 0.6546 & 80 \\
SIZE & 6.77342 & 1.076371 & 3.6762 & 7.8591 & 80 \\
\hline
\end{tabular}

\section{Source: STATA 11}

Table 1 show that our measure of Investment efficiency (INVEFF), cash paid for acquisition or construction of fixed assets scaled by total assets has an average value of 0.5332762 with standard deviation of 0.205 , and minimum value of 0.0538 and 0.9479 as the maximum value. This is an indication that the data is normally distributed and is fit to produce a reliable result, because the mean is greater than standard deviation. The table also shows that the Accounting conservatism (CON) have an average value of 0.0234 with standard deviation of 0.1867 , and the minimum and maximum value of 0.4951 and 0.6546 respectively. This shows that the data is dispersed from the mean because the standard deviation is higher than the mean. Finally, the average firm size, which is the nature log of total assets is 6.77342 , ranging between 3.68 to 7.86 . Here also, there is an indication that the data are not positively skewed and are fit to produce result that is reliable.

The correlation matrix table 2 shows the relationship between all variables in the study model. The result reveals that firm size is positively correlated with all other variables. While the firm leverage appear to have negative correlation with each of both the investment efficiency and Accounting conservatism. This calls for an investigation of the possibility of multicollinearity. The multicollinearity test using the variance inflation factor (VIF) indicates that the autocorrelation level within the period of the study may not have any statistically significant impact as all VIF are above 1.0 and tolerance values (1/VIF) are less than 1.0. The mean of the VIF is 1.02. Further, the diagnostic statistics obtained from Breusch-pagan/cook-weisberg test for heteroskedasticity indicate that the regression model performs properly, as the chi2 is 1.16 at 0.2813 level of significant. 
Table 2: Correlation Matrix

\begin{tabular}{|c|c|c|c|c|}
\hline VARIABLES & INVEFF & CON & LEVR & SIZE \\
\hline INVEFF & 1 & & & \\
\hline CON & 0.0602 & 1 & & \\
\hline LEVR & -0.6687 & -0.0466 & 1 & \\
\hline SIZE & 0.0413 & 0.2596 & 0.0671 & 1 \\
\hline
\end{tabular}

Source: STATA 11

Table 3. Summary of Regression Results

\begin{tabular}{|c|c|c|c|c|}
\hline Variable & Coefficient & Std. Err. & T. Test & $\mathrm{P}>|\mathrm{T}|$ \\
\hline Constant & -0.2397473 & 0.1321221 & -1.81 & 0.074 \\
\hline CON & 0.0370639 & 0.0164381 & 2.25 & 0.027 \\
\hline LEVR & -0.5204242 & 0.0612899 & -8.49 & 0.000 \\
\hline SIZE & 0.0273472 & 0.015295 & 1.79 & 0.078 \\
\hline R2 & & & & 0.5198 \\
\hline Adj. R2 & & & & 0.5008 \\
\hline F-Statistic & & & & 27.42 \\
\hline Prob. of F & & & & 0.000 \\
\hline
\end{tabular}

\section{Source: STATA 11}

The table 3 is a summary of regression output of the dependent variable (INVEFF) on the explanatory variable (CON) and the Control variables (LEVR, SIZE) presented. From the table, the result indicates that Accounting conservatism is positively related to Investment efficiency with the t-statistic of 2.25 and is significant at $5 \%$, which implies that for every $1 \%$ increase in level of Accounting conservatism, investment efficiency would increase with about 3.7\%. This gave us basis to strongly belief that there is significant and positive relationship between accounting conservatism and investment efficiency. Thus, we reject the null hypothesis that says there is no significant relationship between accounting conservatism and investment efficiency. This result extend the findings of Verdi (2006), Biddle (2006), McNichols and Stubben (2008), Lara et al (2009, 2010a, 2010b), Brockman, Liu and Ma (2010), Lalbar et al (2012), Mahmoodabadi and Mehtari (2012), Nuanpradit and Boonlert-u-Thai (2013), Ghavi, Najafi and Arfai (2013), Nakano, Otsubo and Takasu (2014), Mansoori et al (2014).

From the result, the cumulative $\mathrm{R}^{2}(0.52)$ which is the multiple coefficient of determination gives the proportion of the total variation in the dependent variable explained by the explanatory variables jointly. Hence, it signifies $52 \%$ of total variation in investment efficiency of Nigerian listed conglomerate firms is caused by their level of accounting conservatism, copula with level leverage and total assets. The Adjusted Coefficient of determination Adj $R^{2}(0.50)$ indicates the explanatory power of the independent variables which are able to describe $50 \%$ of dependent variable changes too and the F-statistic value is 27.42 and is significant at $1 \%$. This indicates that the model is fit and the explanatory variable are properly selected, combined and used, thus, the study findings can be reliable.

The findings of the study have several theoretical, practical and regulatory implications. These implications represent the contributions of the study which are expected to benefit the existing body of knowledge within 
the accounting research, regulators, providers of accounting services and investors. Our findings have important policy implications since they suggest the need to encourage applying Accounting conservatism principles by institutions and individual mangers to provide effective monitoring of investment level in the Nigerian conglomerate firms, especially those with a large amount of leverage, that is, the large the leverage the lower investment efficiency. This suggests that similar efforts in other sectors especially financial institutions would be good help in controlling their investment decisions in order to promote economic efficiency and resolve the conflicts between the bondholders (the financiers) and shareholders over share dividends.

Furthermore, in line with Suijs (2008), Lara et al (2010) and Laibar et al (2012) this study suggest that Accounting conservatism do more good than harm to the Accounting practices and principles, therefore eliminating the element of accounting conservatism by Financial Reporting Council/International Financial Reporting Standard Board is similar to pursuing the adverse economic consequences.

Finally, our findings shed more light on accounting conservatism and investment efficiency studies in the sense that Nigerian conglomerate firms are more conservative in nature, thus firm commitment to conservatism can lead to a direct benefit to international and local investors in the form of more efficient investments.

\section{Conclusion and Recommendation}

Conclusively, the study has provided both empirical as well as statistical evidence on the Accounting conservatism in explaining and predicting Investment efficiency of the Nigerian listed conglomerate firms. Thus, Conservatisms influencing Investment efficiency of Nigerian conglomerate firms. It is therefore recommended that conditional conservatism used in this study as proxy of Accounting conservatism should be encouraged by the regulating bodies/standard setters and all other stakeholders especially, those in the Nigerian conglomerate firms because of the role that the Accounting conservatism play in constraining managers to act efficiently in an investment monitoring and decision making. Finally, this study confirms that accounting conservatism can reduce cost of capital (Lara et al2009, Xu, Wang and Han 2012). However, the study does not investigate whether the reduced costs of capital will translate into increased capital investments, which is one of the limitations of this study suggested for further research.

\section{References}

Ahmed, A. S., B.K. Billings, R. M. Morton and M. Stanford-Harris. (2002). the role of accounting conservatism in mitigating bondholder-shareholer conflicts over dividend policy and in reducing debt costs. The accounting Review, 77(4): 867-890.

Ahmed, A.S. and S. Duellman. (2007a). Evidence on the role of accounting conservatism in monitoring managers' investment decisions. Working paper, Texas A\&M University.

Ahmed, A.S. and S. Duellman. (2007b). Evidence on the role of accounting conservatism in corporate governance. Journal of accounting and Economics, 43:41 - 437 .

Ball, R. and L. Shivakumar (2005). Earnings quality in UK private firms: comparative loss recognition timeliness. Journal of Accounting and Economics, 39: 83-128.

Ball, Ray, S.P. Kothari, and Ashok Robin, (2000) The Effect of International Institutional Factors on Properties of Accounting Earnings, Journal of Accounting and Economics, 29(1), 1-51.

Basu, S. (1997). The conservatism principle and the asymmetric timeliness of earnings. Journal of Accounting and Economics. 24: 3-37.

Biddle, G.C., and G. Hilary. (2006). Accounting quality and firm - level capital investment. The Accounting Review $81(5): 963-982$.

Biddle, G., Hilary, G., \& Verdi, R. S. (2009). How Does Financial Reporting Quality Relate to Investment Efficiency? Journal of Accounting and Econonmics 48, 112-131. 
Brochman P.,Liu M. And Ma T. 2010. Accounting conservatism and Corporate Investment. American Accounting Association (AAA) Annual comference.

Bushman, R.M., J.D. piotroski and A.J. Smith. (2007). Capital allocation and timely accounting recognition of economic losses. Working paper, University of Chicago.

Bushman. R.M. and A.J. Smith. (2001). Financial accounting information and corporate governance. Journal of Accounting and Economics, 32: 237-333.

Financial Accounting Standards Board (FASB), Statement of Financial Accounting Concepts No.8: Conceptual Framework for Financial Reporting, Chapter 1, The Objective of General Purpose Financial Reporting, and Chapter 3, Qualitative Characteristics of Useful Financial Information, FASB, 2010.

Gary C. Biddle, Mary L.Ma, Franek M. song , (2010) “Accounting conservatism and Bankvuptcy Risk” Faculty of Business and Economics The university of Hong Kong.

Geimechi G. and Khodabakhshi N. 2015. Factors affecting the level of accounting conservatism. International jounal of accounting research. 2(4) 41-46.

Ghavi K., Najafi Y., and Arfai A. 2013. The study of effect of accounting conservatism on the flexibility of the financial decisions. International research jounal of Applied and basic sciences. 4(1) 131-138.

Guay, W. and R. Verrecchia. (2007). Conservative disclosure. Working paper, University of Pennsylvania.

Hope, K.O. and W.B. Thomas. (2008). Managerial empire building and firm disclosure. Journal of Accounting Research, 46(3): 591-626.

Jensen, M.J. . 1986. Agency costs of free cash flow, corporate finance and takeovers. AmericanEconomic Review $76(2): 323-329$.

Jensen, M.J. and W. Meckling. (1976). Theory of the firm: Managerial behavior, agency costs and ownership structure. Journal of Financial Economics, 28: 51-82.

Julio, B. 2007. Overcoming overhang: agency costs, investment and the option to repurchase debt. Working paper, London Business School.

Kieso, E. Donald, Weygandt, Jerry.J, Warfield, D.Terry. 2001. IntermediateAccounting Book John Wiley \& Sons, Inc.

LaFond, R. and R.L. Watts. (2008). The information role of conservatism. The Accounting Review, 83(2): $447-478$.

Lalbar A.,G. Mehdi, P. M. Hosein and karamali M. 2012. A study of the relationship between accounting conservatism and investment efficiency, jounal of basic and applied scientific research. 2(6) 5719-5725.

Lambert, R.A., C. Leuz and R.E. Verrecchia. (2007). Accounting information, disclosure and the cost of capital. Journal of Accounting Research, 45(2): 385-420.

Lara, J. M., Garcia Osma, B., \& Penalva, F. (2009). Accounting Conservatism and Corporate Goverannce. Review of Accounting Studies 14, 161-201.

Lara, J. M., Garcia Osma, B., \& Penalva, F. (2010b). Conditional Conservatism and Costof Capital. Review of Accounting Studies forthcoming.

Lara, J. M., Garcia Osma, B., \& Penalva, F. (2010a). Conditional Conservatism and Firmlnvestment Efficiency. Working Paper , Universidad Carlos III de Marid.

Mahmoodabadi H. and Mehtari Z. 2012. The association between Accounting conservatism and investment efficiency. Jounal of accounting advances (JAA). 3(2) 15-17. 
Mansoori Azam and Kiamehr Ali 2014. Studying the role of accounting conservatism and institutional investors on investment process. Indian jounal of fundamental and applied life science. 4(4) 2850-2859.

McNichols, M.F., and S.R. Stubben. (2008). Does earnings management affect firms' investment decisions? The Accounting Review, 83(6) 1571-1603.

Myers, S. C. (1977). Determinants of corporate borrowing. Journal of Financial Economics 5 147-175.

Myers, S., \& Majluf, N. (1984). Corporate financing and investment decisions when firms have information that investors do not have. Journal of Financial Economics 13 157-187.

Nakano M., Otsubo F., and Takasu Y. 2014. Effects of accounting conservatism on corporate investment level, risk taking, and shareholders value. IMES Discussion paper series 2014-E-10.

Nuanprdit S. and Boonlert-U-Thai K. 2013. Accounting conservatism and future investment opportunities. Proceedings of global business and finance research conference.

Schleicher, T., A. Tahoun and M. Walker. (2008). IFRS adoption in Europe and Investment - Cash Flow Sensitivity: Outsider versus Insider Economies. Working paper. Manchester Business School.

Suijs, J. (2008). On the value relevance of asymmetric financial reporting policies. Journal of Accounting Research, 46(5): 1297-1321.

Stein, J.C. 1989. Efficient capital markets, inefficient firms: A model of myopic corporate behavior. Quarterly Journal of Economics 104(4): 655-669.

Verdi, R.S. (2006). Financial reporting quality and investment efficiency. Working paper, MIT.

Xu X, Wang X and Han N (2012).Accounting conservatism, ultimate ownership andinvestment efficiency, China Finance Review International 2(1) $53-77$. 


\section{Appendix:}

- describe

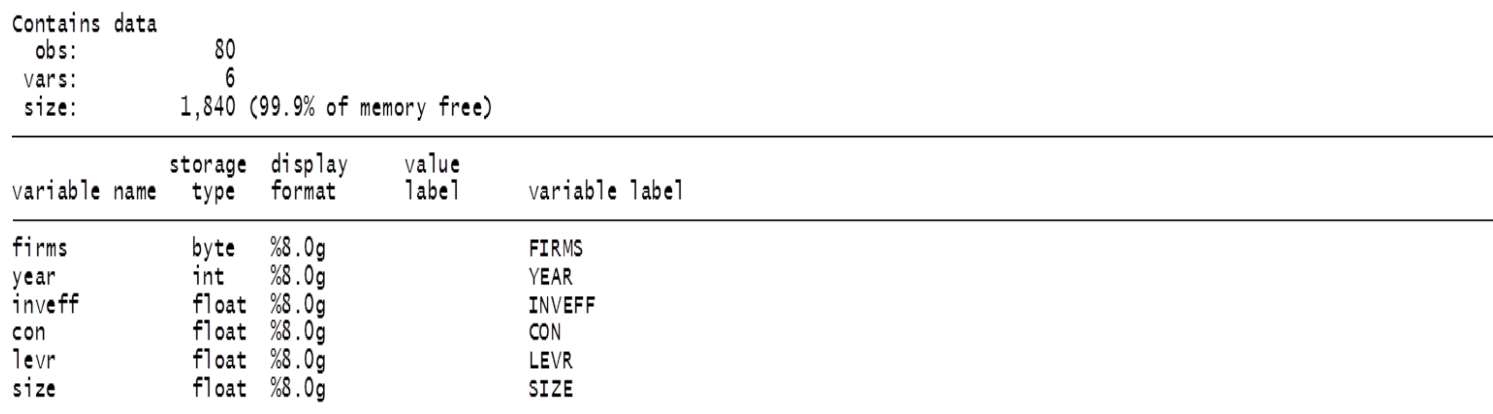

Sorted by:

Note: dataset has changed since last saved

. summarize inveff con levr size

\begin{tabular}{r|rrrrr} 
Variable & obs & Mean & std. Dev. & Min & Max \\
\hline inveff & 80 & .5332762 & .2048363 & .0538 & .9479 \\
con & 80 & .0234287 & .1866834 & -.4951 & .9022 \\
levr & 80 & .1992225 & .0951834 & .0446 & .6546 \\
size & 80 & 6.77342 & 1.076371 & 3.6762 & 7.8591
\end{tabular}

- correlate inveff con levr size (obs=80)

\begin{tabular}{r|rrrr} 
& inveff & con & levr & size \\
\hline inveff & 1.0000 & & & \\
con & 0.0602 & 1.0000 & & \\
levr & -0.6687 & -0.0466 & 1.0000 & \\
size & 0.0413 & 0.2596 & 0.0671 & 1.0000
\end{tabular}

. swilk inveff con levr size

shapiro-wilk w test for normal data

\begin{tabular}{r|rcccc} 
Variable & Obs & $W$ & $V$ & $z$ & Prob $>z$ \\
\hline inveff & 80 & 0.96804 & 2.194 & 1.721 & 0.04260 \\
con & 80 & 0.98520 & 1.016 & 0.034 & 0.48646 \\
levr & 80 & 0.92553 & 5.112 & 3.575 & 0.00018 \\
size & 80 & 0.70459 & 20.277 & 6.594 & 0.00000
\end{tabular}

. vif

\begin{tabular}{r|rr} 
Variable & VIF & $1 /$ VIF \\
\hline levr & 1.03 & 0.973862 \\
size & 1.02 & 0.978224 \\
con & 1.02 & 0.981197 \\
\hline Mean VIF & 1.02 &
\end{tabular}


. hettest

Breusch-Pagan / Cook-weisberg test for heteroskedasticity

Ho: Constant variance

Variables: fitted values of inveff

$\operatorname{chi2}(1)=1.16$

Prob $>$ chi2 $=0.2813$

- regress inveff con levr size

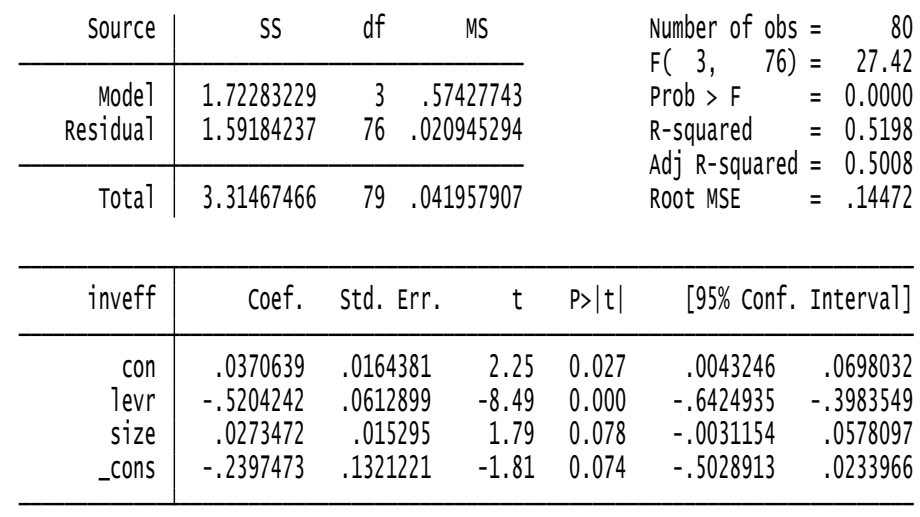

